\title{
WAWRZYNIEC KOWALSKI
}

Wojskowa Akademia Techniczna

ORCiD: 0000-0002-7426-9593

\section{Stanowisko Polskiej Partii Socjalistycznej wobec zamachu majowego w 1926 roku}

Tragiczne wydarzenia zamachu majowego z 1926 roku są wciąż żywe w pamięci współczesnych, pozostając prawdopodobnie najistotniejszą cezurą dzielącą okres rządów parlamentarno-gabinetowych od rządów obozu piłsudczykowskiego w dwudziestoleciu międzywojennym. Pomimo tak dużego upływu czasu, okoliczności, jak również poglądy i role odegrane przez kluczowych uczestników tych wydarzeń do dziś albo pozostają bliżej nieznane, albo też budzą wciąż żywe spory. Należy do nich stanowisko PPS wobec zamachu w 1926 roku, interesujące dla badacza tym bardziej, że nie sposób nie docenić wielkiej roli, jaką Partia ta odegrała w II Rzeczypospolitej. Roli zarówno bezpośredniej — vide udział socjalistów w pierwszych gabinetach Polski niepodległej czy też ich znaczny wpływ na kształt konstytucji marcowej - jaki i pośredniej, której przykładem jest chociażby przyczynienie się tego ugrupowania do upadku gabinetu Aleksandra Skrzyńskiego ${ }^{1}$. Celem artykułu jest więc ukazanie stosunku Polskiej Partii Socjalistycznej do zamachu w 1926 roku. W artykule prześledzono, w jaki sposób osoba Józefa Piłsudskiego zaważyła na decyzji socjalistów, dotyczącej poparcia idei zamachu majowego. Podjęto również próbę odpowiedzi na pytanie, czy faktycznie poparcie przez PPS zamachu majowego było błędem. Analizie poddano także relacje panujące ówcześnie wśród socjalistów skupionych wokół Polskiej Partii Socjalistycznej.

Relacje na linii sanacja-Polska Partia Socjalistyczna w dwudziestoleciu międzywojennym najczęściej kojarzy się z opozycyjnym po 1926 roku stosunkiem tej partii do piłsudczyków lub też kontrapunktycznie - z członkostwem

${ }^{1}$ Szerzej temat wpływu lewicy parlamentarnej na strukturę naczelnych władz państwa: W. Kowalski, Koncepcje ustrojowe izby wyższej parlamentu w II Rzeczypospolitej, Warszawa 2014. 
Marszałka Józefa Piłsudskiego w Organizacji Bojowej Polskiej Partii Socjalistycznej $^{2}$. Współcześnie powszechnie zwykło się postrzegać stosunki pomiędzy Józefem Piłsudskim a klubem parlamentarnym PPS przez pryzmat wyborów brzeskich w 1930 roku czy też ostrego sporu pomiędzy Komendantem a Marszałkiem Sejmu, Ignacym Daszyńskim, zainicjowanego 31 października 1929 roku, a dotyczącego odmowy otwarcia obrad sejmu w związku z obecnością w holu parlamentu licznej grupy uzbrojonych oficerów towarzyszących Piłsudskiemu ${ }^{3}$. Wszakże należy zauważyć, że do 1926 roku lewica sejmowa darzyła Józefa Piłsudskiego głęboką atencją bazującą nie tylko na jego lewicowej proweniencji. Z socjalistami Marszałek był również powszechnie kojarzony, nie bez powodu więc krótko charakteryzowano Piłsudskiego słowami: „Socjalista. Konspirator. Legionowy brygadier. Naczelnik Państwa i Naczelny Wódz. Zamachowiec. Dyktator"4. Jak wiadomo, to z ruchu socjalistycznego Piłsudski wyszedł i ruch ten rzutował na jego dalsze losy. Socjaliści postrzegali go również jako męża stanu, który był zdolny przeciwstawić się ugrupowaniom prawicy. W retoryce jego wystąpień z pierwszej połowy lat dwudziestych nie brakowało przykładów wrogości do prawicy. Już Andrzej Ajnenkiel, pisząc o Piłsudskim w okresie jego dobrowolnego wygnania do Sulejówka, wskazywał: „Niezwykle ostro atakował endecję, moralnie odpowiedzialną za śmierć Narutowicza. Już samo to wystarczało, by lewica sejmowa uznawała go za swą sztandarową postać" 5 .

Zwracając uwagę na relacje pomiędzy Józefem Piłsudskim i jego szerokim oraz zróżnicowanym zapleczem politycznym a kierownictwem Polskiej Partii Socjalistycznej w pierwszej połowie lat dwudziestych, nie wolno zapominać, że Marszałek cieszył się dużym poparciem, jeśli nie wśród ścisłego kierownictwa ugrupowania, to bez wątpienia wśród rzeszy szeregowych członków ${ }^{6}$. Kwestię

${ }^{2}$ Należy zauważyć, że Józef Piłsudski stał na czele legendarnej Organizacji Bojowej PPS. Był zresztą znakomitym organizatorem w partii — szerzej na ten temat J. Piłsudski, Bibuła, Warszawa 2009.

3 Typowym przykładem nieustających konfliktów obozu pomajowego z klubem PPS były częste konfiskaty wydawanego w Warszawie „Robotnika” będącego oficjalnym organem partii. Odbywały się one z polecenia Komisarza Rządu w Warszawie - generała Felicjana Sławoja-Składkowskiego. Przykładem reakcji w związku z konfiskatą tytułu na forum izby niższej była wypowiedź posła Mieczysława Niedziałkowskiego w dniu 5 lipca 1926 roku: „Zwracam się więc do p. Marszałka, jako do najwyższego strażnika praw Sejmu i związanych z nim praw podstawowych demokracji parlamentarnej, żeby zechciał się zwrócić [...] z prośbą i żądaniem, aby pouczyli podwładnych im urzędników, że naruszanie Konstytucji najzupełniej przekracza granice ich kompetencji, i że Rząd, którego urzędnicy nie szanują Konstytucji, nie ma prawa wymagać szanowania jego zarządzeń przez społeczeństwo". Sprawozdanie Stenograficzne z 290. posiedzenia Sejmu z dnia 5 lipca 1926 roku, łam. 5.

${ }^{4}$ W. Suleja, Józef Pitsudski, Wrocław 2005, s. 5. Por. również idem, Józefa Pitsudskiego koncepcje odzyskania niepodległości, „Przegląd Historyczno-Wojskowy” 2007, nr 5, s. 11 n.

5 A. Ajnenkiel, Parlamentaryzm II Rzeczypospolitej, Warszawa 1975, s. 214.

6 Popularność Józefa Piłsudskiego w mniejszych ośrodkach miejskich wśród elektoratu lewicy była znaczna. Szerzej kwestię tę omawia m.in. Jan Jerzy Milewski na przykładzie wojewódz- 
sympatyzowania części członków partii PPS z Marszałkiem szczegółowo omówił już w literaturze Ludwik Hass ${ }^{7}$. O tym świadczy zresztą fakt wydania w kwietniu 1926 roku Manifestu do ludu pracującego, w którym to propagowano pogląd, że Józef Piłsudski znów powinien stanąć na czele wojska ${ }^{8}$. Widoczna była wówczas oczywista i nieukrywana sympatia znacznej części socjalistów wewnątrz niejednorodnej wewnętrznie PPS do osoby Marszałka Piłsudskiego. Nadmienić warto, że jego zwolennicy nie tworzyli w obrębie ugrupowania jednej, zwartej frakcji czy stronnictwa, co w znacznym stopniu utrudnia ustalenie niejawnych działań i zaangażowania członków PPS w przygotowanie zamachu majowego. W obrębie ugrupowania tak rozbudowanego, jak ówczesna PPS, można zidentyfikować zarówno piłsudczyków sensu stricto, jak Jędrzej Moraczewski, Marian Malinowski, Medard Downarowicz, Zofia Prausowa czy Romuald Jaworski, jak i działaczy życzliwych Marszałkowi, takich jak Ignacy Daszyński. Ci ostatni po maju 1926 roku przeszli na stanowiska zdecydowanie opozycyjne względem tzw. obozu pomajowego. Wspomniany Ludwik Hass wskazywał, że środowiska zinfiltrowane przez piłsudczyków wewnątrz partii obejmowały

całą gamę postaw od działaczy typu współpracującego z policją polityczną M. Malinowskiego (Wojtka), czy głoszącego — w słowach — swą wierność ideologii PPS-Frakcji Rewolucyjnej R. Jaworowskiego, do ewoluującego ku syndykalizmowi J. Moraczewskiego. Grupę tę niewiele na ogół łączyło z socjalizmem, a nawet ze światopoglądem demokratycznym. Niektórzy jej działacze w ogóle nie mieścili się w ramach najbardziej nawet szeroko pojmowanego socjalizmu i byli na prawo od najbardziej prawicowych kierunków socjalistycznych w skali międzynarodowej ${ }^{9}$.

Ewidentnym dowodem popularności Piłsudskiego wśród socjalistów był również fakt zaproponowania Marszałkowi przez ugrupowania lewicowe w sejmie objęcia stanowiska prezesa rady ministrów w trakcie przesilenia politycznego w 1926 roku. Jak można było oczekiwać, Józef Piłsudski propozycję tę odrzucił, nie chcąc ograniczać kluczowej dla niego swobody działania na scenie politycznej. Było to zresztą typowe dla Marszałka unikanie nazbyt wiążącej deklaracji po którejkolwiek ze stron ówczesnej sceny politycznej. Ponadto, objęcie stanowiska prezesa rady ministrów byłoby niczym innym, jak bierną akceptacją istniejącej struktury organów naczelnych państwa, wynikającej z tak pogardzanej przez komendanta konstytucji.

twa białostockiego - J.J. Milewski, Polska Partia Socjalistyczna w województwie białostockim 1918-1939, Białystok 1990, s. 134 n.; także Józef Ławnik na przykładzie województwa kieleckiego - J. Ławnik, Działalność PPS w województwie kieleckim w latach 1918-1939. Część pierwsza1918-1930, Kielce 2003, s. 71 n.; czy też Halina Frąckowiak-Kleszowska na przykładzie Grudziądza - H. Frąckowiak-Kleszowska, Działalność Polskiej Partii Socjalistycznej w Grudziądzu w okresie międzywojennym (1920-1939), Grudziądz 2017, s. 45 n.

7 L. Hass, Ksztaltowanie się lewicowego nurtu w Polskiej Partii Socjalistycznej na tle sytuacji wewnatrzpartyjnej (listopad 1923-maj 1926), „Kwartalnik Historyczny” 1961, nr 1, rocznik LXVIII, s. 69-105.

8 Manifest do ludu pracującego, [b.m.w], [b.d.w].

9 L. Hass, op. cit., s. 74. 
Andrzej Ajnenkiel wskazywał na popularność wśród ugrupowań lewicy idei silnego przywództwa:

Jednocześnie w propagandzie adresowanej przez lewicę sejmową do jej zwolenników nie brakowało akcentów bonapartystowskich, stwierdzeń, że remedium na wszystkie trudności stanowi objęcie władzy przez Piłsudskiego, który utworzy rząd demokratyczny z udziałem przedstawicieli robotników i chłopów. Łączyło się to z poparciem, a co najmniej usprawiedliwieniem wszystkich działań Piłsudskiego, jako mających na celu wyłącznie walkę z prawicą ${ }^{10}$.

Andrzej Garlicki podkreślał, że socjaliści z osobą Piłsudskiego wiązali duże nadzieje, już wtedy, gdy ministrowie z ramienia PPS zasiadali w gabinecie kierowanym przez Aleksandra Skrzyńskiego:

Obawiano się również i piłsudczyków, ale uważając ich za grupę pozbawioną szerokiego zaplecza społecznego, przewidywano, że będą musieli szukać oparcia w lewicy parlamentarnej. Było to więc zło mniejsze - i jak wierzono - dające się oswoić ${ }^{11}$.

Z chwilą rozpoczęcia 12 maja 1926 roku na ulicach Warszawy działań zbrojnych przez zbuntowane oddziały wojska wierne Piłsudskiemu swoją pomoc zaoferowały Marszałkowi związki zawodowe oraz ugrupowania polityczne o rodowodzie lewicowym. Szczególne znaczenie dla skuteczności działań piłsudczyków w trakcie przewrotu miało poparcie udzielone zamachowcom przez środowiska zawodowe kolejarzy, tradycyjnie związane z Polską Partią Socjalistycz$n^{12}$. W jego następstwie na dłuższy czas skutecznie zablokowano strategiczną magistralę kolejową prowadzącą na Mazowsze z Wielkopolski. Rozebranie fragmentów torów kolejowych znacznie spowolniło dotarcie do stolicy jednostek wojskowych wiernych rządowi Wincentego Witosa ${ }^{13}$. Zresztą utrudnienia w transportowaniu wojsk rządowych do Warszawy nie ograniczały się jedynie do Wielkopolski i Mazowsza - wystąpiły one również w innych częściach kraju ${ }^{14}$.

10 A. Ajnenkiel, op. cit., s. 222.

11 A. Garlicki, Józef Piłsudski 1867-1935, Kraków 2017, s. 477.

12 Można mniemać, że znaczny wpływ na skuteczność i zaangażowanie związków zawodowych kolejarzy występujących po stronie zamachowców miała m.in. mobilizacja tego środowiska, spowodowana programem refom Jerzego Zdziechowskiego. Jednym z elementów reformy miało być zwolnienie tysięcy kolejarzy. Była to jedna z przyczyn podania się do dymisji przedstawicieli PPS w rządzie. Jednocześnie działanie to uwiarygodniło intencje socjalistów w oczach przedstawicieli potężnych związków zawodowych.

13 Nie był to wszakże czynnik decydujący o skuteczności przewrotu wojskowego. Utrudnienia czynione przez kolejarzy w przerzucie wojsk strony wiernej rządowi do stolicy były istotne, natomiast w ciągu kilku dni siły zbrojne dysponowały możliwościami militaryzacji kolei.

14 Przykładem może być tu chociażby meldunek specjalny 4 powiatowej Komendy Policji województwa śląskiego w Katowicach w związku z wydarzeniami w kraju z dnia 14 maja 1926 roku. Stwierdzono w nim m.in.: „Ze Lwowa wyjechały dwa pułki, które jednak przez tamtejszych kolejarzy zostały wstrzymane”. To samo źródło podawało: „W dyrekcji krakowskiej został proklamowany strajk kolejarzy. Okolicznościowe odezwy wydadzą związki zawodowe w godzinach popołudniowych, nawołujące do strajku powszechnego. Maszyniści na parowozach otrzymali polecenie, żeby 
Należy przypomnieć, że z inicjatywy PPS na dzień 14 maja 1926 roku proklamowany został w państwie strajk powszechny. Stosowne odezwy wydał Centralny Komitet Wykonawczy PPS oraz Okręgowe Komitety Robotnicze. Przykładowo, Warszawski OKR informował czytelników wydawanego w Warszawie „Głosu Kobiet":

Warszawski Okręgowy Komitet Robotniczy PPS ogłosił strajk powszechny i uchwalił: wezwać wszystkich robotników i pracowników miasta Warszawy do powszechnego strajku w dniu 14 b.m. aż do odwołania. [...] Niech strajk ten będzie potężną manifestacją na rzecz Józefa Piłsudskiego, jego bohaterskiej armii i Rządu robotniczo-włościańskiego ${ }^{15}$.

Wraz z zakończeniem przewrotu majowego i podaniem się trzeciego rządu Witosa do dymisji nie od razu oczywiste było, jak wyglądają dalsze polityczne zamierzenia Józefa Piłsudskiego. Hasło tzw. sanacji, dotyczące uzdrowienia stosunków politycznych w kraju, stanowiło z jednej strony wygodne dla niego słowo-klucz, z drugiej zaś pozostawiało otwarte drzwi do współpracy z potencjalnie szerokim spektrum ugrupowań politycznych. Sam zamach odbył się za aprobatą ugrupowań lewicowych, które pragnęły interpretować go jako wyraz swoistego poparcia dla ich stanowiska $\mathrm{w}$ walce $\mathrm{z}$ ugrupowaniami prawicy. W ramach doraźnej taktyki politycznej lewica uznała, że fakt zbrojnego wystąpienia Piłsudskiego można wykorzystać do realizacji własnych założeń programowych. Takiemu tokowi rozumowania ze strony PPS sprzyjało, po pierwsze, traktowanie przez socjalistów swojego dawnego towarzysza z Organizacji Bojowej PPS jako osoby wciąż im życzliwej ${ }^{16}$, a po drugie — fakt, że Marszałek kategorycznie unikał przed majem 1926 roku jakichkolwiek deklaracji politycznych. Współcześnie w doktrynie podkreśla się znaczenie uczestnictwa Marszałka w ruchu socjalistycznym i wskazuje, że to z kolei powodowało, iż z lewicą Komendant zaczął być powszechnie kojarzony.

Punktem wyjścia myśli politycznej Józefa Piłsudskiego był socjalizm. [...] Taki też pogląd przyjęło wielu współczesnych Piłsudskiemu Polaków, tworzących co do zasady po 1906 roku PPS Frakcję Rewolucyjną ${ }^{17}$.

o godzinie 20:00 wstrzymać wszelki ruch i parowozy winny udać się do parowozowni” — P. Kołakowski, A. Pepłoński, Majowy zamach stanu w świetle dokumentów wywiadu, dyplomacji i organów bezpieczeństwa II Rzeczypospolitej, Słupsk 2008, s. 30-31.

15 Wiadomości z ostatniej chwili, „Głos Kobiet. Wydawnictwo Centralnego Wydziału Kobiecego P.P.S." Warszawa, 14 maja 1926 roku, s. 1.

${ }^{16}$ Wydawali się oni nie dostrzegać, że z chwilą odzyskania niepodległości Piłsudski dbał o to, by nie być utożsamianym z dawnymi partyjnymi towarzyszami. Andrzej Friszke akcentuje ponadto, że Piłsudskiego nigdy kwestie ideowo-programowe jako takie nie zajmowały. Jego zdaniem Marszałek koncentrował się wyłącznie na ,praktyce socjalistycznej”. Por. szerzej A. Friszke, Panel politologiczno-historyczny. Glos w dyskusji, [w:] Polska Partia Socjalistyczna. Szkice. Polemiki. Wspomnienia. Dlaczego się nie udało?, red. R. Spałek, Warszawa 2010, s. 394.

17 A. Bosiacki, Ewolucja myśli polityczno-państwowej Józefa Pitsudskiego oraz jej wpływ na myśl społeczna i dokonania Drugiej Rzeczypospolitej, „Studia nad Autorytaryzmem i Totalitaryzmem" 37, 2015, nr 2, s. 8. 
Należy pamiętać, że obóz sanatorów z Piłsudskim na czele objął władzę kompletnie nie mając jakiegokolwiek programu politycznego, który de facto zastępowała doraźnie sama osoba Marszałka ${ }^{18}$. Jak wiadomo, program taki zaczął być gruntownie wypracowywany dopiero wraz z utworzeniem przez płk. Walerego Sławka Bezpartyjnego Bloku Współpracy z Rządem ${ }^{19}$. W końcu wydaje się również, że poparcie akcji majowej Piłsudskiego przez Polską Partię Socjalistyczną było swoistym zagraniem va banque, nastawionym na znalezienie się po stronie zwycięzcy w konflikcie z rządem Wincentego Witosa ${ }^{20}$.

Owa niejasność zamierzeń powodowała, że lewica projektowała objęcie steru rządu osobiście przez Piłsudskiego, jednakże on poleciłł na to stanowisko rektora Politechniki Lwowskiej — profesora Kazimierza Bartla. Fiaskiem skończyła się również próba zaproponowania Piłsudskiemu urzędu prezydenta Rzeczypospolitej. Odmowa Marszałka w tej kwestii stanowiła dla socjalistów znaczne zaskoczenie i powód rozgoryczenia. Zdumienia władz naczelnych PPS nie ukrywano na łamach oficjalnego dziennika partii — „Robotnika”

stwierdzić trzeba, że odmowa Piłsudskiego — po tak świetnym wyniku kampanii — była zupełną niespodzianką. Albowiem w toku akcji za wyborem Piłsudskiego nic tej odmowy nie zapowiadało. Piłsudski nie protestował przeciwko swojej kandydaturze, nie zaprzeczył wiadomości Polski Zbrojnej, że wybór przyjmie. Sobotnie przemówienie Piłsudskiego w Prezydium Rady Ministrów, pomimo swej często bardzo dziwacznej formy, było raczej zapowiedzią, że Piłsudski wybór przyjmie. [...] Okazało się niestety, że istniało tu duże nieporozumienie. [...] Demokracja pragnęła realnego Prezydenta w osobie Piłsudskiego, realnego wyboru. I pod tym względem zawiodła się 21 .

18 Brak wypracowanej koncepcji sprawowania władzy i przemyślanego programu politycznego u piłsudczyków w doktrynie podkreślali m.in. A. Bosiacki, Pomiędzy państwem prawnym a autorytaryzmem. Z polskich rozważań nad poszukiwaniem optymalnego ustroju państwa po odzyskaniu niepodległości w III Rzeczypospolitej, „Studia nad Autorytaryzmem i Totalitaryzmem” 38, 2017, nr 4, s. 100 n.; W.T. Kulesza, Koncepcje ideowo-polityczne obozu rządzacego w Polsce w latach 1926-1935, Wrocław 1985.

19 Zresztą program sanatorów nie wykrystalizował się praktycznie aż do uchwalenia w 1935 roku nowej konstytucji. Egzemplifikacją braku programu politycznego były trudności w stworzeniu ostatecznej wersji konstytucji. Doskonałym przykładem mogą być chociażby eksperymenty ustrojowe Walerego Sławka. Por. W. Kowalski, Koncepcje ustrojowo-polityczne izby drugiej obozu piłsudczykowskiego po przewrocie majowym, „Studia Iuridica” 2014, t. 59, s. 177 n.; T. Chłopecki, Koncepcje elitaryzmu w myśli Walerego Stawka, „Prace z myśli polityczno-prawnej oraz prawa publicznego" 2012, s. 139 n.

20 Trzeba zauważyć, że potencjalni antagoniści marszałka Piłsudskiego w maju 1926 roku nie ograniczali się tylko do rządu Wincentego Witosa i sił prawicy. Marszałek musiał się mierzyć, i faktycznie zmierzył się, z opozycyjną względem piłsudczyków pokaźną częścią korpusu generalskiego w wojsku. Stwierdzenie, że J. Piłsudski cieszył się w wojsku niekwestionowanym autorytetem, byłoby sformułowaniem nieprawdziwym. Dobitnym przykładem takiego stanu rzeczy był toczący się do 1926 roku spór odnoszący się do struktury najwyższych władz wojskowych (zwłaszcza pozycji ustrojowej Naczelnego Wodza). Należy również zwrócić uwagę na pomajowe losy niektórych wybitnych generałów pozostających w opozycji do Komendanta: Włodzimierza Zagórskiego, Juliusza Malczewskiego czy też Tadeusza Rozwadowskiego.

21 Wczorajszy wybór i nowa sytuacja, „Robotnik” nr 149, 1 czerwca 1926 roku, s. 1. 
Ewidentne było więc wykorzystanie sejmowej lewicy do realizacji doraźnych zamierzeń zwycięzcy majowych zmagań, przyczyniając się ponadto do pewnej deprecjacji znaczenia lewicy sejmowej w oczach opinii publicznej. Wskazuje się, że potencjalni beneficjenci zamachu — w tym przypadku lewica — ponieśli de facto porażkę: „Efektem ustrojowym przewrotu było [...] osłabienie prestiżu władzy, parlamentu i partii politycznych, także tych, które popierały przewrót i kandydaturę Piłsudskiego na prezydenta RP"22

Wraz z zakończeniem walk ulicznych socjaliści uznali, że nadszedł odpowiedni moment, by rozpocząc realizację ich programu politycznego. Nadzieje ugrupowań lewicy następująco skomentował Andrzej Ajnenkiel:

Zwycięstwo Piłsudskiego utwierdziło partie lewicy sejmowej w przekonaniu, że zostaną zrealizowane ich postulaty. Podjęły one kampanię propagandową za wybraniem Marszałka na urząd prezydenta, rozwiązaniem sejmu i senatu oraz zarządzeniem nowych wyborów. [...] Sam zwycięzca zachowywał się powściągliwie. Deklarował, że nie jest zwolennikiem ani lewicy, ani prawicy, że należy unikać eksperymentów socjalnych ${ }^{23}$.

Ta wypowiedź Piłsudskiego, jak się wydaje, powinna być sygnałem ostrzegawczym dla socjalistów, że Marszałek definitywnie zakończył wyznawanie ideałów socjalistycznych. Jednakże, pomimo tej deklaracji PPS, podobnie jak i inne ugrupowania, w dniu 31 maja 1926 roku w trakcie prac Zgromadzenia Narodowego mających na celu wybór prezydenta na urząd opuszczony po dymisji Stanisława Wojciechowskiego zgłosiła kandydaturę właśnie Piłsudskiego. W wyniku głosowania Marszałek dostał dwieście dziewięćdziesiąt dwa głosy, jego kontrkandydat zaś, hrabia Adolf Bniński — sto dziewięćdziesiąt trzy. Jak wiadomo, Piłsudski ostentacyjnie urzędu nie przyjął: wysunął zastępczą kandydaturę znanego naukowca, w młodości socjalisty — profesora Ignacego Mościckiego. Wyznaczenie Mościckiego na eksponowane stanowisko głowy państwa umożliwiło Marszałkowi skoncentrowanie się na tworzeniu zaplecza politycznego. Współcześnie akcentuje się pragmatyzm w działaniu Piłsudskiego. „Piłsudski nie myśląc o realizacji reform społecznych proponowanych przez lewicę parlamentarną, kładł nacisk na umocnienie swej pozycji w państwie"24.

W tej sytuacji PPS zaproponowała własnego kandydata na urząd głowy państwa — krakowskiego adwokata i przewodniczącego Związku Parlamentarnego Polskich Socjalistów, Zygmunta Marka, który na ten urząd wcześniej zgłosił Józefa Piłsudskiego ${ }^{25}$. Kandydaturę wysuniętą przez PPS należy interpretować, jak się wydaje, wyłącznie jako działanie noszące charakter doraźnej taktyki politycznej, obliczonej na podkreślenie swojego stanowiska wobec elektoratu lewicy. Wiado-

22 M.M. Drozdowski, Józef Pitsudski 1867-1935. Myśl i działalność polityczna, Stalowa Wola 2017, s. 253.

23 A. Ajnenkiel, op. cit., s. 243-244.

24 W.T. Kulesza, op. cit., s. 13.

${ }^{25}$ Kandydatura ta zgłoszona została podczas posiedzenia Zgromadzenia Narodowego w dniu 31 maja 1926 roku. 
me było, że Marek nie miał żadnych szans w starciu czy to z Ignacym Mościckim, czy to $z$ Adolfem Bnińskim, tak więc w drugim głosowaniu parlamentarzyści PPS głosy oddali już za Mościckim wskazanym przez Marszałka. Poparcie PPS nie ograniczyło się zresztą do kwestii personalnych. Lewica opowiedziała się również za głosowaną w dniu 22 czerwca 1926 roku ustawą o prowizorium budżetowym, a przeciwko antypiłsudczykowskim poprawkom wprowadzonym do tego prowizorium przez senat.

Poparcie przez socjalistów Józefa Piłsudskiego w pierwszej fazie majowego przewrotu oraz szybkie, późniejsze zdystansowanie się PPS od Marszałka do dzisiaj budzi niejasności i skłania do przemyśleń. Pisano wprost o tzw. błędzie majowym polskich socjalistów ${ }^{26}$. O błędzie w kalkulacjach CKW PPS wspominali również inni badacze ${ }^{27}$. W doktrynie spotyka się pogląd, że jedną z najistotniejszych porażek PPS w okresie międzywojennym było „,[p]rzegranie konfrontacji z Józefem Piłsudskim" ${ }^{28}$. Pytanie, które należy zatem postawić, dotyczy tego, czy faktycznie uznanie za błąd udzielenia poparcia twórcom zamachu w 1926 roku przez socjalistów było uzasadnione. Jak się wydaje, odpowiedź nie jest ani prosta, ani też do końca możliwa z punktu widzenia współczesnego badacza funkcjonującego w dzisiejszych realiach. Na obecne oceny tamtych wydarzeń mniej lub bardziej pośrednio oddziałuje świadomość bilansu rządów sanacji, jak również niekompletność źródeł i relacji świadków.

Poparcie i życzliwość ze strony części kierownictwa socjalistów wobec zbrojnego zamachu stanu nie ulega wątpliwości. Ale poza życzliwością każda wszakże poważna partia polityczna kieruje się swoistym pragmatyzmem w osiąganiu celów politycznych. Należy więc zapytać, co faktycznie kierowało liderami PPS, że w swoich politycznych rachubach uznali udzielenie poparcia zbrojnemu zamachowi stanu za opłacalne. Na wstępie można wyróżnić kilka kluczowych powodów, choć oczywiście nie jest to i nie może być lista zamknięta.

Po pierwsze, liderzy ugrupowania w wystąpieniu Piłsudskiego upatrywali szansy realizacji postulatów partii. Efektem miała być rewolucja socjalna zawarta w programach socjalistów ${ }^{29}$. Liczono, że działanie Marszałka umożliwi dalsze utrwalanie się systemu rządów parlamentarnych, zagrożonych zdaniem socjalistów dyktaturą prawicy. Jednocześnie należy zauważyć, że immanentną cechą

${ }^{26}$ M. Śliwa, ,Błą majowy” polskich socjalistów, [w:] Zamach stanu Józefa Pitsudskiego i jego konsekwencje w interpretacjach polskiej myśli politycznej XX wieku, red. Z. Karpus, W. Wojdyło, Toruń 2008 , s. $131 \mathrm{n}$.

27 J. Tomicki, Polska partia socjalistyczna 1892-1948, Warszawa 1983, s. 284 n.

28 S. Michałowski, PPS w okresie II Rzeczypospolitej - sukcesy i porażki, [w:] Polska Partia Socjalistyczna. Szkice..., s. 14.

29 Szerzej na temat rewolucji bez elementów rewolucyjnych pisał W. Kowalski, Demokratyzm a autorytaryzm PPS wobec zamachu majowego i rządów sanacji, publikacja pokonferencyjna, Warszawa 2018. 
ustroju, do ustanowienia którego socjaliści dążyli, miało być utrzymanie istotnej roli legislatywy w systemie ustrojowym państwa ${ }^{30}$.

Po drugie, rozumowano, że skoro Marszałek występuje zbrojnie przeciwko trzeciemu rządowi Wincentego Witosa, pojawia się w końcu szansa zajęcia miejsca koalicji PSL PIAST i Związku Ludowo-Narodowego.

Po trzecie, w PPS funkcjonowało głęboko zakorzenione przekonanie, że Piłsudski to wciąż ten sam człowiek partii, który w 1894 roku został redaktorem naczelnym wydawanego nielegalnie „Robotnika”31. Andrzej Ajnenkiel tak pisał o poparciu Marszałka i samego zamachu przez lewicę:

Nie spotkałoby się to [zamach — przyp. aut.] z oporem stronnictw lewicy sejmowej. [...] Bezpośrednio po zwycięstwie ugrupowania lewicy sejmowej podjęły kampanię zmierzającą do natychmiastowego rozwiązania sejmu i senatu oraz przekazania funkcji Prezydenta Piłsudskiemu. Postulowano zarazem utworzenie rządu lewicowego czy — jak to inaczej formułowano - rządu robotniczo-włościańskiego. [...] W rezolucjach, zwłaszcza organizacji prowincjonalnych stronnictw lewicowych, żądano ,,pełni władzy” dla Piłsudskiego ${ }^{32}$.

Jak miało się wkrótce okazać, przekonanie to było złudne - sięganie przez Marszałka do idei socjalistów miało charakter doraźny i wiązało się z , raczej instrumentalnym traktowaniem haseł socjalistycznych"33. Jednocześnie należy zaznaczyć, że we wcześniejszym okresie, gdy Marszałek pełnił funkcję Naczelnika Państwa, tj. do 1922 roku PPS także okazywała życzliwość działaniom Piłsudskie$\mathrm{go}^{34}$. Podkreśla się, że przywiązanie do wyidealizowanego wizerunku Marszałka funkcjonowało w partii jeszcze długo po 1926 roku: „W szeregach PPS wciąż jeszcze bardzo silny był mit Piłsudskiego" ${ }^{\text {"35 }}$. Należy dodać, że mit ten był tak silny, że dość długo władze naczelne PPS nie próbowały mu się przeciwstawiać.

Jako czwarty powód poparcia Piłsudskiego należy podać obecność zwolenników Marszałka w kierownictwie partii — vide działalność m.in. Jędrzeja Moraczewskiego $^{36}$. Ten ostatni nie skonsultował nawet swojego udziału w rządzie pomajowym z władzami klubu, którego de facto był członkiem ${ }^{37}$. Było to

30 Należy nadmienić, że socjaliści odrzucali koncepcję parlamentu bikameralnego, dążąc do utworzenia jednoizbowego Sejmu wspieranego ewentualnie przez tzw. Izbę Pracy.

31 Szerzej o dorobku Józefa Piłsudskiego w okresie jego czynnego udziału w PPS w: J. Piłsudski, Bibuła, Warszawa 1990.

32 A. Ajnenkiel, Polska po przewrocie majowym. Zarys dziejów politycznych Polski 19261939, Warszawa 1980, s. 8-14.

33 J. Holzer, PPS. Szkic dziejów, Warszawa 1977, s. 24-25.

34 Szerzej na ten temat pisał J. Holzer, op. cit., s. 103.

35 K. Piskała, Ku Rzeczypospolitej Socjalistycznej. Studium z dziejów myśli politycznej PPS (1929-1939), Łódź 2017, s. 207.

36 Obecność sympatyków i realizatorów koncepcji politycznych Marszałka w innych ugrupowaniach politycznych szerzej omawia A. Chojnowski, Piłsudczycy u władzy. Dzieje Bezpartyjnego Bloku Wspótpracy z Rządem, Wrocław 1986.

37 Stało się to zresztą przyczyną usunięcia Jędrzeja Moraczewskiego z szeregów partii. Szerzej na ten temat pisał m.in. J. Gołota, Jędrzej Moraczewski. Pierwszy premier II Rzeczypospolitej, Ostrołęka 2002, s. $180 \mathrm{n}$. 
klarowne złamanie dyscypliny partyjnej. Nie można również nie docenić życzliwości wobec Komendanta ze strony członków Partii Socjalistycznej na niższych szczeblach partii. Na istotne wpływy piłsudczyków w omawianym ugrupowaniu wskazują badacze, którzy dokonali analizy dokumentów wywiadu i innych służb z okresu zamachu majowego. Ich zdaniem

przygotowania do przewrotu majowego [...] zostały zapoczątkowane już jesienią 1925 roku. Wskazywało na to prowadzenie przez członków PPS, byłych legionistów i dawnych członków Polskiej Organizacji Wojskowej, intensywnej propagandy skierowanej przeciwko endecji. Akcji tej przewodzili związani blisko z Marszałkiem: Jędrzej Moraczewski, Rajmund Jaworski i Marian Malinowski ${ }^{38}$.

Zwłaszcza ten ostatni, będący niekwestionowanym liderem lubelskiej organizacji PPS, był typowym działaczem partyjnym, który w rzeczywistości bezwzględnie realizował polecenia Marszałka. Na przykładzie lubelskiej organizacji PPS ukazano, jak dalece środowisko lewicy było spenetrowane przez piłsudczyków, co ostatecznie miało poważny wpływ na poparcie zamachowców w 1926 roku:

M. Malinowski sprawujący niemal dyktatorskie rządy w lubelskiej organizacji PPS. Należał on do najbardziej zagorzałych piłsudczyków i antykomunistów w PPS. [...] Jego komunizm łączył się nierozerwalnie z bezgranicznym poparciem Piłsudskiego [...]. W okresie II Rzeczypospolitej jego koronną tezą było twierdzenie, że tylko endecja i komuniści nie pozwalają Piłsudskiemu na odrodzenie Polski ${ }^{39}$.

Ostatnim powodem, który paradoksalnie odegrał istotną rolę w poparciu zamachu majowego, była konspiracja towarzysząca przewrotowi i jego nagłość. Zamiary Marszałka były okryte głęboką tajemnicą, nawet jego bliscy współpracownicy nie do końca orientowali się co do zamierzeń przywódcy. Doskonałym przykładem pokazującym stopień utajnienia przygotowań do zbrojnego wystąpienia było zaskoczenie Kazimierza Świtalskiego wybuchem zajść w stolicy. Należy przypomnieć, że był on jednym z najbliższych i najwierniejszych podwładnych Marszałka ${ }^{40}$. W zeznaniach złożonych w sierpniu 1953 roku powiedział m.in.:

Czynności przygotowawcze do marszu oddziałów wojskowych w kierunku gmachu Sztabu Generalnego były robione przez Piłsudskiego przez osobiste zetknięcie się z dowódcami tych formacji w sposób poufny z uwagi na to, że Piłsudski wówczas żadnej władzy formalnej nad wojskiem nie posiadał. Polecenia jego były przyjmowane przez dowódców tych formacji na skutek uznawania przez nich autorytetu moralnego jego jako byłego ich Naczelnego Wodza. Jako osoba wówczas nie wojskowa ani o tych przygotowaniach ani o dacie marszu nie byłem uprzednio poinformowany zarówno przez samego Piłsudskiego jak i przez jego zwolenników z osób wojskowych. Mam pewność że Piłsudski o przygotowaniach w/w nie mówił z żad-

38 P. Kołakowski, A. Pepłoński, op. cit., s. 5.

39 B. Pawłowski, Polska Partia Socjalistyczna na Lubelszczyźnie w okresie listopad 1923maj 1926, „Annales Universitatis Mariae Curie-Skłodowska, sectio F” 1975, t. XXX, s. 33.

40 Nie bez znaczenia dla braku wtajemniczenia Świtalskiego w plany spiskowców było może to, że pozostawał w rezerwie. Szerzej na ten temat T. Serwatka, Kazimierz Switalski (1886-1962). Biografia Polityczna, Warszawa 2009, s. 42. 
nymi osobami nie wojskowymi, bo znając charakter Piłsudskiego wiedziałem, że w takich wypadkach ograniczał się do informowania tylko tych osób, które miały brać w akcji udział bezpośredni ${ }^{41}$.

Józef Piłsudski, doświadczony konspirator z okresu walki z caratem, doskonale zdawał sobie sprawę ze znaczenia właściwego utajnienia informacji. Bazował na relacjach osobistych z podwładnymi, słusznie bojąc się pozostawienia wszelkiej korespondencji. Dostęp do informacji w obliczu znacznego rozłamu w armii z założenia nie mógł być ułatwiony. Nie bez znaczenia dla stopnia tajności była wymierzona w Piłsudskiego działalność kontrwywiadu wojskowego, działającego na polecenie rządu ${ }^{42}$. Dostrzec trzeba też, że osoby, poprzez które Piłsudski koordynował akcję zamachu majowego, miały w większości przeszłość wojskową i doceniały kwestię dochowania tajemnicy wojskowej. Niejasność i tajemniczość wydarzeń towarzyszących zamachowi poruszył w doktrynie Andrzej Garlicki, którego zdaniem ,nie istniała konspiracja wojskowa w sensie zorganizowanej struktury" "33. Jak się wydaje, bliższe prawdy będzie nazwanie grupy czołowych oficerów armii skupionych wokół Marszałka i osób mu posłusznych grupą legionowo-peowiacką.

Wskazano, że zaskoczenie faktem zamachu uniemożliwiło uważniejsze przemyślenie kwestii jego poparcia przez partię:

partia była zamachem Piłsudskiego nie tylko zdeprymowana ale i zdezorientowana. Niemniej zamach poparła. Ale w to poparcie była wmanewrowana i wymanewrowana też. Decyzja o strajku kolejarzy, w przeddzień zamachu, była w dużym stopniu elementem decydującym o jego powodzeniu. [...] Strajk powszechny, ogłoszony przez partię 14 maja, sprawę przesądził. Zagrały tu z pewnością stare sentymenty. I resentymenty też ${ }^{44}$.

Lewica sejmowa nie wiedziała również, do ustanowienia jakiego ustroju Piłsudski dąży. Wiadomo było, że uważa system konstytucyjny bazujący na wszechwładzy sejmu za skompromitowany jego nieudolnością. Z tym Marszałek nigdy się nie krył. Zresztą na podstawie ogólnikowych wypowiedzi Piłsudskiego trudno byłoby zorientować się, jakie są jego konkretne zamierzenia ustrojowe. Ten brak skonkretyzowanych poglądów stwarzał również jego podwładnym

41 P. Duber, Nieznana relacja Kazimierza Świtalskiego na temat zamachu majowego, „Dzieje Najnowsze" XLVII, 2015, s. 224. Należy pamiętać wszakże, że w chwili składania zeznań przez Świtalskiego pozostawał on w więzieniu od listopada 1948 roku. Dlatego też jest możliwe, że celowo pomniejszał swoją rolę w wydarzeniach 1926 roku.

42 Co zresztą nie może dziwić, jeśli wziąć pod uwagę, iż usunięcie się przez Piłsudskiego w cień Sulejówka było przez rząd traktowane wyjątkowo nieufnie. Nie sprzyjały temu manifestacje, i to ostentacyjne, poparcia dla Marszałka ze strony wyższych oficerów w służbie czynnej, jak ta z 15 listopada 1925 roku. Wówczas, pod pretekstem rocznicy powrotu Marszałka z Magdeburga, w willi Piłsudskiego w Sulejówku zameldowało się kilkuset oficerów, w tym czterech generałów. Do legendy przeszła wypowiedź gen. Orlicza-Dreszera, w której tak wysoki rangą oficer sugerował gotowość podwładnych do buntu.

43 A. Garlicki, op. cit., s. 461. Autor ów stosuje również określenie „grupa kierownicza”.

44 R. Stefanowski, PPS: 1892-1992, Warszawa 1992, s. 100-101. 
poważne trudności w określeniu, czego tak naprawdę chce Marszałek. Należy przypomnieć, że poseł Bezpartyjnego Bloku Współpracy z Rządem Józefa Piłsudskiego, Adam Piasecki wydał w roku 1931 Tezy Konstytucyjne Marszałka, które miały służyć jako zbiór wskazań dla sanatorów co do poglądów ustrojowych Marszałka. Pomimo obfitości cytatów, dokładnych wskazań co do przyszłego ustroju państwa znaleźć tam jednak nie można ${ }^{45}$. Trudno więc było liczyć, że PPS poza mglistymi enuncjacjami prasowymi Komendanta zorientuje się co do jego rzeczywistych zamiarów. Jak wskazano, decyzja o wsparciu przewrotu była dla znacznej części kierownictwa klubu — zaznaczmy, że tej niewtajemniczonej — niemalże spontaniczna. „Ale wtedy, w trakcie rozgrywania się tragedii majowej, na głębszą dyskusję nie było czasu. A tą co była przerwał Daszyński, kiedy na jednej z narad zwołanych ad hoc powiedział: »Co my tutaj mamy gadać i rozcinać włos na czworo, kiedy tam Piłsudski się bije «"46. Jednocześnie zaś współcześnie pewna niefrasobliwość ze strony władz PPS musi dziwić, jeśli wziąć pod uwagę, że od 1925 roku opinia publiczna regularnie karmiła się częstymi plotkami o zbliżającym się zamachu kierowanym przez Piłsudskiego. Cała ówczesna scena polityczna żyła w głębokim przekonaniu, że pobyt Marszałka na przysłowiowym ,zesłaniu” w Sulejówku ma charakter tymczasowy i dobrowolny. Jedyne, czego wówczas nie wiedziano, to którą drogę powrotu do czynnego życia politycznego Piłsudski wybierze.

W dniach po zamachu kierownictwo klubu liczyło, że pod kierunkiem Marszałka rozpocznie się dynamiczna zmiana stosunków społecznych w kraju. Liczono, że Piłsudski rozpocznie realizację postulatów socjalistów. Interesujące jest, iż z chwilą zakończenia wymiany ognia na ulicach Warszawy i podania się prezydenta Wojciechowskiego do dymisji Piłsudski czynił szybkie starania o niedopuszczenie do polaryzacji sceny politycznej na piłsudczyków wraz ze wspierającą ich lewicą sejmową i prawicę. Wymownym tego przykładem może być znamienne spotkanie Marszałka w październiku 1926 roku z przedstawicielami ziemiaństwa w Nieświeżu. Był to pierwszy tak istotny krok mający na celu umożliwienie sanatorom uzyskania trwałego poparcia ze strony ugrupowań i środowisk konserwatywnych. W działaniach Piłsudskiego, podjętych przez niego po maju, widać wyraźnie, że starał się on uniknąć sytuacji bycia swoistym zakładnikiem któregoś z obozów politycznych. Wypowiedź Marszałka: ,zrobiłem jedyny

45 A. Piasecki, Tezy konstytucyjne Marszałka Piłsudskiego. Referat wygłoszony w dniu 28 lutego 1931 roku u marszałka Senatu Władystawa Raczkiewicza, Warszawa 1931. Na marginesie rozważań należy wskazać, że Józef Piłsudski parł do władzy z — w rzeczywistości — pustym programem politycznym. Konkretnych postulatów i rozwiązań ustrojowych Marszałek nie sformułował. Zagadnienie tworzenia się doktryny konstytucyjnej obozu sanacyjnego omawia szerzej A. Bosiacki, Ewolucja myśli polityczno-państwowej..., s. 17 n., jak również N. Baranowska i T. Chłopecki, Koncepcje ustrojowo-prawne obozu rzadzacego w II Rzeczypospolitej w latach 1926-1932, [w:] Rodzinna Europa. Europejska myśl polityczno-prawna u progu XXI wieku, red. P. Fiktus, H. Malewski, M. Marszał, Wrocław 2015.

46 R. Stefanowski, op. cit., s. 101. 
w swoim rodzaju fakt historyczny, żem zrobił coś podobnego do zamachu stanu i potrafił go natychmiast zalegalizować i żem uczynił coś w rodzaju rewolucji bez żadnych rewolucyjnych konsekwencji" ${ }^{47}$ może być interpretowana, jako niedopuszczenie do sytuacji wyodrębnienia na scenie politycznej dwóch obozów: szeroko rozumianego piłsudczykowskiego oraz związanego z obalonym rządem Wincentego Witosa. Zdystansowanie się Piłsudskiego od życzliwej w dniach przesilenia majowego PPS nie dziwi gdy zwróci się uwagę, że zamach majowy poparła również Komunistyczna Partia Polski oraz blisko z nią współpracująca, radykalna w swoich poglądach Niezależna Partia Chłopska czy też Niezależna Socjalistyczna Partia Pracy. Mniemać można, że to właśnie z nimi i z ich poparciem Piłsudski nie chciał być utożsamiany.

Warto przyjrzeć się również motywom, dla których w burzliwych dniach maja 1926 roku Polska Partia Socjalistyczna zdecydowała się poprzeć zamach stanu dokonywany przez część sił zbrojnych wiernych Marszałkowi. Dla większości współczesnych poglądy ustrojowe PPS w dwudziestoleciu międzywojennym kojarzą się z okresem, w którym lewica parlamentarna pozostawała w całkowitej opozycji do obozu sanatorów i utożsamiała się z realizacją swoich socjalistycznych postulatów wyłącznie w oparciu o formułę rządów demokratycznych, bazujących na poszanowaniu prawa i władzy legislatywy.

Należy pamiętać, że paradoksalnie realizacja celów politycznych przez partię w ustroju demokratyczno-republikańskim nie stanowiła jedynego, rozważanego przez socjalistów w okresie międzywojennym rozwiązania. Już u progu uzyskania przez Rzeczpospolitą niepodległości środowisko PPS było podzielone pod względem rozpatrywanych dróg realizacji programu socjalistycznego. Dyskusje programowe toczące się na XIV Zjeździe Polskiej Partii Socjalistycznej w Warszawie we wrześniu 1918 roku skupiały się na wyborze modelu przyszłego państwa polskiego, a co za tym idzie, drogi do osiągnięcia zamierzonego celu.

Na zjeździe starły się trzy kierunki polityki PPS. Grupa lewicowej młodzieży socjalistycznej i reemigrantów z Rosji wypowiadała się za dążeniem do realizacji Polski socjalistycznej zorganizowanej w państwo dyktatury proletariatu. Prawicowi działacze socjalistyczni, przeważnie związani z obozem J. Piłsudskiego, propagowali myśl utworzenia rządu konsolidacji narodowej, obejmującego zarówno lewicę niepodległościową, jak też ugrupowania prawicy społecznej. Najbardziej wpływową grupę na zjeździe stanowili działacze związani z F. Perlem, zwolennicy — jak ich określał M. Niedziałkowski — tzw. socjalizmu demokratycznego ${ }^{48}$.

W pierwszych latach po wojnie wśród socjalistów skupionych w Polskiej Partii Socjalistycznej ostatecznie przeważył pogląd, iż realizacja ich postulatów powinna odbywać się na drodze parlamentarnej, a więc należy działać w oparciu o obowiązującą, choć zdaniem socjalistów niedoskonałą, konstytucję. Wśród czołowych działaczy ugrupowania panowało przekonanie, że modyfikacja

47 J. Piłsudski, Pisma zbiorowe, t. IX, Warszawa 1937, s. 18.

48 M. Śliwa, Polska myśl socjalistyczna 1918-1948, Wrocław 1988, s. 9-10. 
istniejących stosunków społeczno-gospodarczych w państwie w drodze rewolucyjnej nie jest ani możliwa, ani też opłacalna. Wyrazem tych przekonań była m.in. wypowiedź ówczesnego redaktora naczelnego „Robotnika”, Feliksa Perla na XVII Zjeździe PPS odbywającym się w dniach 24-26 maja 1920 roku w Krakowie:

W najbliższej przyszłości nie możemy liczyć na to, że rewolucja rychło wybuchnie i zmieni zasadniczo sytuację w kraju. Mamy do czynienia z ruchem niezadowolenia szerokich mas, które jednak nie może doprowadzić do obalenia w bliskiej przyszłości istniejącego systemu rządów burżuazyjnych ${ }^{49}$.

Koniec złudzeń władz naczelnych partii co do możliwości wyzyskania zamachu majowego i ostateczne przejście na stanowiska opozycyjne względem sanatorów nastąpił stosunkowo szybko — już pod koniec grudnia 1926 roku odbyły się sesja Rady Naczelnej PPS oraz posiedzenie Centralnego Komitetu Wykonawczego PPS, podczas których przyjęto uchwały o stosunku partii do nowego rządu. Obrady Rady Naczelnej wyraźnie pokazały, że piłsudczycy wciąż mieli we władzach PPS pewne wpływy, lecz stopniowo ulegli majoryzacji. Jan Tomicki pisał:

W rezultacie Rada Naczelna pod presją silnej grupy piłsudczykowskiej złagodziła nieco uchwałę w sprawie stosunku PPS do rządu. Stwierdzono zatem, że partia nie zmierza do obalenia premiera, marszałka Piłsudskiego, lecz do rekonstrukcji jego gabinetu przez usunięcie zeń żywiołów monarchistycznych i reakcyjnych. Niemniej był to zwrot w polityce PPS ${ }^{50}$.

Trudno zgodzić się z tą opinią wskazującą na posiadanie przez piłsudczyków istotnych wpływów w Radzie Naczelnej. Świadczy o tym wynik głosowania Rady Naczelnej, które odbyło się w dniu 20 grudnia 1926 roku i dotyczyło poparcia w drodze uchwały wcześniejszego stanowiska Centralnego Komitetu Wykonawczego odnośnie do przejścia przez partię do opozycji. Od jego poparcia wstrzymało się jedynie trzech członków Rady (sic!), czterdziestu jeden zaś opowiedziało się za stanowiskiem CKW PPS. Pomimo przejścia ugrupowania na pozycję opozycyjną widać wyraźnie, iż liderzy partii starali się za wszelką cenę nie doprowadzić do sytuacji zaostrzenia relacji na linii PPS-Piłsudski. Sama uchwała RN PPS, przedrukowana na łamach „Robotnika”, napisana została językiem ugodowym — np.: „Rada Naczelna przyjmuje do wiadomości uchwałę CKW o zajęciu stanowiska opozycyjnego, powziętą na skutek kierunku dotychczasowej polityki gospodarczej Rządu oraz pewnych aktów, zwróconych przeciw zasadom demokracji politycznej" ${ }^{51}$. Widać wyraźnie, że liderzy klubu starali się nie uczynić z przyjętej uchwały swoistej odezwy politycznej godzącej osobiście w Piłsudskiego i dezawuującej jego osobę w oczach swojej klienteli politycznej. RN PPS wystąpiła za to przeciwko obecności w rządzie, kierowanym od 2 października

\footnotetext{
49 XVII Zjazd PPS, „Naprzód” nr 125, 27 maja 1920 roku, s. 1.

50 J. Tomicki, op. cit., s. 291.

51 Uchwaty Rady Naczelnej, „Robotnik, nr 350, 21 grudnia 1926 roku, s. 1.
} 
1926 roku przez Józefa Piłsudskiego, dwóch przedstawicieli konserwatywnego ziemiaństwa: ministra sprawiedliwości, Aleksandra Meysztowicza oraz ministra rolnictwa, Karola Niezabytowskiego. W podobnym tonie utrzymana została późniejsza - z dnia 18 grudnia - uchwała CKW PPS, w której to CKW czynił zarzuty obozowi sanatorów za „tajemniczość, jaka otacza program i zamiary szefa władzy wykonawczej" ${ }^{52}$. Ponadto, sprzeciw lewicy dotyczył udziału wielkiego kapitału w rządzie. Krytykowano także „,chaos ideowy w Radzie Ministrów”53. Jednakże w uchwale CKW znalazło się również odniesienie do autora zamachu majowego:

Powiedzieliśmy sobie: przechodzimy do opozycji nie po to, by obrywać liście z wieńca sławy Józefa Piłsudskiego, nie po to, by ze złośliwością ulicznika szukać w każdej okoliczności sposobu dla rzucenia kamieniem czy obelgą; wręcz przeciwnie: przechodzimy do opozycji, bo chcemy, by kierownicy Państwa zdali sobie sprawę, że realnego układu sił społecznych nie zmieni nikt i nic $[\ldots]^{54}$.

Pomimo swoistej troski wyrażonej w cytowanym fragmencie, a dotyczącej kierownictwa państwa, wspominany dokument powinien być interpretowany raczej jako przyznanie się do porażki poniesionej przez władze PPS. Porażki zarówno w sferze doraźnej taktyki politycznej, jak i w sferze ideologicznej. O ile wskazane działanie w trybie doraźnym może z dzisiejszego punktu widzenia być zrozumiałe - chodziło wszakże o szybkie opowiedzenie się po stronie, jak słusznie zresztą mniemano, zwycięskiego Marszałka, a co za tym idzie o dojście do władzy - o tyle poparcie zamachu przeciwko legalnym i konstytucyjnym organom państwa zadawało kłam oficjalnej ideologii partii. PPS, już od 1908 roku, w swoich programach politycznych wyraźnie wskazywała na konieczność realizacji zamierzeń politycznych drogą legalną. Legalną, a więc parlamentarną i w świetle obowiązującego prawa. Akceptacja zamachu i jego późniejsza legitymizacja poprzez poparcie kandydatury Józefa Piłsudskiego była już poważnym błędem. Zresztą nasuwa się tu skojarzenie ze znanym powiedzeniem Karola Maurycego de Talleyranda, że popełnienie błędu jest czynem gorszym niż dokonanie zbrodni ${ }^{55}$. Podobnie należy zapatrywać się na jeden z mniej znanych współcześnie postulatów, zgłoszony przez CKW PPS w dniu 15 maja 1926 roku: „Złodzieje grosza publicznego piastujący urzędy państwowe, a zwłaszcza byli ministrowie: Kucharski, Witos, Kiernik, Osiecki, Zdziechowski, Korfanty, Moszczeński mają być doraźnie ukarani" ${ }^{56}$. Dziwić może fakt, że ugrupowanie, które ostatecznie porzuciło stosowanie rewolucyjnego radykalizmu w swoim programie

52 Jedność w partii, „Robotnik” nr 348, 19 grudnia 1926 roku, s. 1.

53 Ibidem.

54 Ibidem.

55 Szerzej na ten temat J. Orieux, Talleyrand, Warszawa 1989.

56 Stronnictwa lewicowe wobec sytuacji, „Głos Polski. Dziennik polityczny, społeczny i literacki” 17 maja 1926 roku, s. 1. 
politycznym, zdecydowało się na formułowanie takich postulatów ${ }^{57}$. Życzliwość CKW wobec idei sądzenia w trybie doraźnym za wyimaginowane przestępstwa wpisywała się w nurt pozyskiwania kapitału politycznego w oparciu o hasło rozliczenia prawicy sejmowej — konkretnie koalicji tworzącej trzeci rząd Witosa.

Kolejny błąd, który popełnili socjaliści, wynikał z utrzymywania się w partii złudnego, jak miało się okazać, przekonania, że Józef Piłsudski stanowi w rzeczywistości niemal personifikację sił zbrojnych. Legenda Piłsudskiego, starannie budowana na niwie zwycięskiej wojny z bolszewikami oraz okresu sprawowania funkcji Naczelnika Państwa, a także wcześniejszych, legionowych zasług, nie przekładała się wprost na realia. Znaczna część kadry dowódczej w armii była wroga lub co najmniej niechętna Piłsudskiemu ${ }^{58}$. Dawni legioniści, z których wielu aktywnie działało w PPS, kultywowali wszakże nimb Piłsudskiego. Partyjni liderzy podjęli decyzję o wyrażeniu poparcia dla Marszałka praktycznie natychmiast, głównie pod wpływem autorytetu Jędrzeja Moraczewskiego. Istotą wspomnianego błędu było poparcie walk zbrojnych w stolicy. Wszakże czym innym jest poparcie zbrojnej demonstracji, czym innym zaś zaangażowanie się w walki uliczne. Doskonałym przykładem takiego działania było postępowanie Okręgowego Komitetu Robotniczego PPS w Łodzi. W dniu 14 maja 1926 roku OKR w wydanym dodatku nadzwyczajnym pisał: „Robotnicy w Łodzi i w całym województwie przygotowują się żywiołowo i zbierają się pod rozkazami PPS do wystąpienia czynnego w razie potrzeby na wezwanie CKW. W masach panuje nastrój przyjazny dla toczącej się walki z reakcją" ${ }^{59}$. W podobnym tonie wypowiadały się inne Okręgowe Komitety Robotnicze. Zaryzykować można stwierdzenie, że w maju 1926 roku Polskiej Partii Socjalistycznej bliżej było do metod stosowanych w 1907 roku przez PPS Frakcję Rewolucyjną. Współcześnie podkreśla się nastrój członków partii na wieść o zamachu: „Z wielkim entuzjazmem przyjęli więc i poparli członkowie partii akcję Józefa Piłsudskiego, która miała ugruntować demokratyczno-parlamentarny system sprawowania władzy"60.

Podsumowując, należy zaznaczyć, że poparcie lewicy dla Marszałka Piłsudskiego nie ograniczało się jedynie do wsparcia wyrażonego deklaracjami politycznymi władz ugrupowania czy też życzliwym przedstawianiem zamachu majowego na łamach oficjalnego organu prasowego Polskiej Partii Socjalistycznej, jakim był wydawany w stolicy „Robotnik”. Wsparcie dla zamachowców było również silne w terenie, czego przykładem mogą być artykuły, które ukazywały się w ówczesnych

57 Szerzej na ten temat W. Kowalski, Demokratyzm a autorytaryzm PPS...

58 W tym względzie wciąż są aktualne ustalenia Jerzego Halbersztadta, który wskazywał, że w dniach majowego przesilenia po stronie Piłsudskiego opowiedziało się zaledwie kilkunastu generałów. Por. J. Halbersztadt, Józef Pitsudski a mechanizm podejmowania decyzji wojskowych w latach 1926-1935, „Przegląd Historyczny” 1983, nr 4, s. 678.

59 „Łodzianin”, dodatek nadzwyczajny z 14 maja 1926 roku, s. 1.

60 S. Michałowski, Polska Partia Socjalistyczna w systemie politycznym II Rzeczypospolitej, „Annales Universitatis Mariae Curie-Skłodowska, sectio F” 1992, vol. XLVI/XLVII, s. 415. 
bastionach lewicy, m.in. Zagłębiu Dąbrowskim. Trzeba podkreślić, że władze krajowe i okręgowe miały mało czasu na wypracowanie jednolitego stanowiska wobec wydarzeń dynamicznie rozgrywających się na ulicach Warszawy. W doktrynie podkreśla się nagłość i szybkość wydarzeń majowych:

Pewne jest natomiast, że kierownictwo ruchu socjalistycznego na rozwój wypadków nie było przygotowane. Poza kilkoma wpływowymi politykami, przede wszystkim Jędrzejem Moraczewskim, zresztą sąsiadem Marszałka w Sulejówku, oraz przywódcą Związku Zawodowego Kolejarzy - Adamem Kuryłowiczem, a także przewodniczącym warszawskiej organizacji PPS - Rajmundem Jaworskim i paroma być może jeszcze innymi osobami - Bronisławem Ziemięckim i Marianem Malinowskim nie wiedziano o przygotowaniach do przewrotu i nie traktowano poważnie pojawiających się o nich informacji ${ }^{61}$.

Zaskoczony CKW PPS ostatecznie wybrał opowiedzenie się po stronie Piłsudskiego. Pod względem ideowym i programowym był to błąd - udzielono bowiem poparcia zamachowi stanu, później zaś starano się zamach ten legitymizować. Poparcie kandydatury Marszałka na urząd głowy państwa obróciło się przeciwko PPS i doprowadziło do faktycznej kompromitacji ugrupowania. $\mathrm{Na}$ omawiane zagadnienie należy spojrzeć również z punktu widzenia obowiązującego w partii od 1920 roku programu politycznego autorstwa Feliksa Perla, przyjętego na XVII kongresie partii w Warszawie. Już we wstępie do programu kierownictwo partii wyraźnie podkreśliło rezygnację ze stosowania radykalnych metod w celu realizacji głównego założenia ugrupowania, mianowicie Polskiej Republiki Socjalistycznej.

Dążenia swoje PPS opiera na rozwoju historycznym stosunków społecznych. [...] Zwycięska rewolucja społeczna umożliwi socjalistyczną przebudowę gospodarczego, politycznego i kulturalnego życia narodów. Lecz urzeczywistnienie tego celu nie może być sprawą krótkiej chwili, nie może być przemocą narzucone społeczeństwu, nie może być niezależne od warunków czasu i miejsca - stanowił program PPS ${ }^{62}$.

Ryszard Szwed, wskazując na odejście ugrupowania od hasła dyktatury proletariatu, pisał: „Stwierdzono, że PPS dąży do ustroju socjalistycznego, ale urzeczywistnienie tego celu nie może być kwestią krótkiej chwili, a tym bardziej nie może być narzucone społeczeństwu siłą"63. Oceniając działanie władz ugrupowania w maju 1926 roku, zaryzykować można więc stwierdzenie, że postępowanie CKW PPS było działaniem co najmniej ambiwalentnym. $Z$ jednej strony PPS podkreślał ewolucyjność swojego programu politycznego: element ten zyskiwał na wartości zwłaszcza w zestawieniu z agresywną retoryką ówczesnej Komunistycznej Partii Robotniczej Polski; z drugiej zaś — poparcie zbrojnego zamachu stanu stało w wyraźnej opozycji do wartości deklarowanych przez socjalistów.

61 M. Śliwa, „Błąd majowy” polskich ..., s. 136.

62 Program Polskiej Partii Socjalistycznej przyjęty na XVII Kongresie w Warszawie w dniach 21-25 maja 1920 roku.

63 R. Szwed, Samorząd terytorialny w polityce i działalności PPS 1918-1939, Łódź 1989, s. 16. 
Z tej wewnętrznej sprzeczności już post factum zdali sobie sprawę w końcu liderzy ugrupowania, stopniowo przechodząc na pozycje mniej, a później bardziej opozycyjne wobec obozu pomajowego. Jak wiadomo, praktycznie już od 1927 roku socjaliści w swoich wypowiedziach i programie uwypuklali konieczność obrony praw legislatywy, plasując się tym samym w opozycji wobec obozu sanacyjnego. Odwołanie się do litery prawa i obrony konstytucji pod koniec lat dwudziestych nie mogło wszakże przesłonić porażki poniesionej przez lewicę. Pisano wręcz: „To moralne zwycięstwo PPS jako partii dostatecznie silnej ideowo, by układy i związki personalne nie mogły jej zagrozić, nie zmienia jednak faktu, że jej realne wpływy na życie kraju uległy znacznemu ograniczeniu" ${ }^{\prime}$. Gdy mówimy o moralnym zwycięstwie, należy jednak pamiętać, że program ugrupowania, ideologia socjalistów czy też poszanowanie ówczesnej konstytucji, jakakolwiek by ona nie była, nie mogą przesłonić faktu, że liderzy PPS nie zawahali się skorzystać z nadarzającej się okazji do szybkiego i całkowicie bezprawnego przejęcia władzy.

Oceniając działanie PPS pod względem zarówno taktycznym, jak i faktycznym, trzeba podkreślić, że poparcie zbrojnego wystąpienia przeciwko rządowi Witosa było działaniem poniekąd słusznym, zamachu stanu bowiem - w ówczesnym mniemaniu przywódców partii — dokonywał mąż opatrznościowy Rzeczypospolitej opromieniony legendą Legionów i wygraną wojną z bolszewikami. Piłsudski był również powszechnie kojarzony z PPS z racji swojej działalności w Organizacji Bojowej PPS. Ugrupowanie tak znaczące na ówczesnej polskiej scenie politycznej, jak Polska Partia Socjalistyczna, nie mogło stać z boku w trakcie krwawych zajść w stolicy. Presja działania, jaką odczuwały na sobie władze naczelne PPS, była również umiejętnie wzmacniana przez wewnątrzpartyjną niejednolitość i frakcyjność, tę zaś, jak wskazano wcześniej, zręcznie potrafili wyzyskać piłsudczycy. Liderzy lewicy, liczący na wykorzystanie popularności Piłsudskiego do swoich celów politycznych, nie zdawali sobie również sprawy z faktycznego zaplecza personalnego, na jakie mógł liczyć Marszałek przy realizacji zamierzeń politycznych ${ }^{65}$. Niewątpliwie należy zaznaczyć, że koncepcja polskich socjalistów, przyjęta w programie partii z chwilą odzyskania niepodległości, polegająca na osiąganiu celów programowych w drodze stopniowych i nierewolucyjnych reform społeczno-politycznych, została paradoksalnie w 1926 roku zarzucona na rzecz rozwiązań charakterystycznych dla ugrupowań rewolucyjnych. Udzielenie poparcia piłsudczykom w procesie zbrojnego pozyskania władzy, w dodatku bez jakiegokolwiek rozpoznania ich celów, stanowiło zatem zaprzeczenie ich politycznego programu. Z dzisiejszego punktu widzenia i w świetle znajomości późniejszych wydarzeń należy stwierdzić, że socjaliści

64 J. Żarnowski, Polska Partia Socjalistyczna, [w:] Życie polityczne w Polsce 1918-1939, red. J. Żarnowski, Wrocław 1985, s. 74.

65 Szerzej kwestię wpływów Józefa Piłsudskiego w ugrupowaniach politycznych ówczesnej sceny politycznej omawia Andrzej Chojnowski, op. cit. 
popełnili błąd - fakt ten nie budzi wątpliwości. Opierając się zaś o recepcję ówczesnych realiów, trzeba przyznać, że Polska Partia Socjalistyczna musiała poprzeć zamach 1926 roku. Innej możliwości socjaliści wówczas ani nie mieli, ani też nie starali się dostrzec. Może więc dlatego redakcja pisała na pierwszej stronie „Robotnika” tryumfalne słowa: „I dziś znowu Piłsudski stoi na czele [...] bohaterskich i szlachetnych przełomów - wielki bojownik i wielki twórca"66.

\section{Bibliografia}

XVII Zjazd PPS, „Naprzód” nr 125, 27 maja 1920 roku.

Ajnenkiel A., Parlamentaryzm II Rzeczypospolitej, Warszawa 1975.

Ajnenkiel A., Polska po przewrocie majowym. Zarys dziejów politycznych Polski 1926-1939, Warszawa 1980.

Baranowska N., Chłopecki T., Koncepcje ustrojowo-prawne obozu rządzacego w II Rzeczypospolitej w latach 1926-1932, [w:] Rodzinna Europa. Europejska myśl polityczno-prawna u progu XXI wieku, red. P. Fiktus, H. Malewski, M. Marszał, Wrocław 2015, s. 257-268.

Bosiacki A., Ewolucja myśli polityczno-państwowej Józefa Piłsudskiego oraz jej wpływ na myśl społeczna i dokonania Drugiej Rzeczypospolitej, „Studia nad Autorytaryzmem i Totalitaryzmem"37, 2015, nr 2.

Bosiacki A., Pomiędzy państwem prawnym a autorytaryzmem. Z polskich rozważań nad poszukiwaniem optymalnego ustroju państwa po odzyskaniu niepodległości w III Rzeczypospolitej, „Studia nad Autorytaryzmem i Totalitaryzmem” 38, 2017, nr 4.

Chłopecki T., Koncepcje elitaryzmu w myśli Walerego Sławka, „Prace z myśli polityczno-prawnej oraz prawa publicznego" 2012.

Chojnowski A., Pitsudczycy u władzy. Dzieje Bezpartyjnego Bloku Wspótpracy z Rządem, Wrocław 1986.

Drozdowski M.M., Józef Piłsudski 1867-1935. Myśl i działalność polityczna, Stalowa Wola 2017.

Duber P., Nieznana relacja Kazimierza Świtalskiego na temat zamachu majowego, „Dzieje Najnowsze" XLVII, 2015.

Frąckowiak-Kleszowska H., Działalność Polskiej Partii Socjalistycznej w Grudziądzu w okresie międzywojennym (1920-1939), Grudziądz 2017.

Friszke A., Panel politologiczno-historyczny. Glos w dyskusji, [w:] Polska Partia Socjalistyczna. Szkice. Polemiki. Wspomnienia. Dlaczego się nie udało?, red. R. Spałek, Warszawa 2010, s. 394 n.

Garlicki A., Józef Pitsudski 1867-1935, Kraków 2017.

Gołota J., Jędrzej Moraczewski. Pierwszy premier II Rzeczypospolitej, Ostrołęka 2002.

Halbersztadt J., Józef Pitsudski a mechanizm podejmowania decyzji wojskowych $w$ latach 19261935, „Przegląd Historyczny” 1983, nr 4.

Hass L., Ksztaltowanie się lewicowego nurtu w Polskiej Partii Socjalistycznej na tle sytuacji wewnatrzpartyjnej (listopad 1923-maj 1926), „Kwartalnik Historyczny” 1961, nr 1, rocznik LXVIII.

Holzer J., PPS. Szkic dziejów, Warszawa 1977.

Jedność w partii, „Robotnik” nr 348, 19 grudnia 1926 roku.

Kołakowski P., Pepłoński A., Majowy zamach stanu w świetle dokumentów wywiadu, dyplomacji i organów bezpieczeństwa II Rzeczypospolitej, Słupsk 2008.

66 „Robotnik” nr 133, 15 maja 1926 roku, s. 1.

Studia nad Autorytaryzmem i Totalitaryzmem 40, nr 2, 2018

(C) for this edition by CNS 
Kowalski W., Demokratyzm a autorytaryzm PPS wobec zamachu majowego i rządów sanacji, publikacja pokonferencyjna, Warszawa 2018.

Kowalski W., Koncepcje ustrojowe izby wyższej parlamentu w II Rzeczypospolitej, Warszawa 2014.

Kowalski W., Koncepcje ustrojowo-polityczne izby drugiej obozu pitsudczykowskiego po przewrocie majowym, „Studia Iuridica” 2014, t. 59.

Kulesza W. T., Koncepcje ideowo-polityczne obozu rządzacego w Polsce w latach 1926-1935, Wrocław 1985.

Ławnik J., Działalność PPS w województwie kieleckim w latach 1918-1939. Część pierwsza1918-1930, Kielce 2003.

„Łodzianin”, dodatek nadzwyczajny z 14 maja 1926 roku.

Michałowski S., Polska Partia Socjalistyczna w systemie politycznym II Rzeczypospolitej, „Annales Universitatis Mariae Curie-Skłodowska, sectio F” 1992, vol. XLVI/XLVII

Michałowski S., PPS w okresie II Rzeczypospolitej — sukcesy i porażki, [w:] Polska Partia Socjalistyczna. Szkice. Polemiki. Wspomnienia. Dlaczego się nie udało?, red. R. Spałek, Warszawa 2010, s. 13-52.

Milewski J.J., Polska Partia Socjalistyczna w województwie białostockim 1918-1939, Białystok 1990.

Orieux J., Talleyrand, Warszawa 1989.

Pawłowski B., Polska Partia Socjalistyczna na Lubelszczyźnie w okresie listopad 1923-maj 1926, „Annales Universitatis Mariae Curie-Skłodowska, sectio F” 1975, t. XXX.

Piasecki A., Tezy konstytucyjne Marszałka Pitsudskiego. Referat wygłoszony w dniu 28 lutego 1931 roku u marszałka Senatu Władystawa Raczkiewicza, Warszawa 1931.

Piłsudski J., Bibuła, Warszawa 2009.

Piłsudski J., Pisma zbiorowe, Warszawa 1937, t. IX.

Piskała K., Ku Rzeczypospolitej Socjalistycznej. Studium z dziejów myśli politycznej PPS (19291939), Łódź 2017.

Program Polskiej Partii Socjalistycznej przyjęty na XVII Kongresie w Warszawie w dniach 21-25 maja 1920 roku.

„Robotnik” nr 133, 15 maja 1926 roku.

Serwatka T., Kazimierz Świtalski (1886-1962). Biografia Polityczna, Warszawa 2009.

Sprawozdanie Stenograficzne z 290. posiedzenia Sejmu z dnia 5 lipca 1926 r.

Stefanowski R., PPS: 1892-1992, Warszawa 1992.

Stronnictwa lewicowe wobec sytuacji, „Głos Polski. Dziennik polityczny, społeczny i literacki” 17 maja 1926 roku.

Suleja W., Józef Piłsudski, Wrocław 2005.

Suleja W., Józefa Piłsudskiego koncepcje odzyskania niepodległości, „Przegląd Historyczno-Wojskowy" 2007, nr 5, s. 11-20.

Szwed R., Samorząd terytorialny w polityce i działalności PPS 1918-1939, Łódź 1989.

Śliwa M., ,Btad majowy” polskich socjalistów, [w:] Zamach stanu Józefa Pitsudskiego i jego konsekwencje w interpretacjach polskiej myśli politycznej XX wieku, red. Z. Karpus, W. Wojdyło, Toruń 2008, s. 131-142.

Śliwa M., Polska myśl socjalistyczna 1918-1948, Wrocław 1988.

Tomicki J., Polska partia socjalistyczna 1892-1948, Warszawa 1983.

Uchwały Rady Naczelnej, „Robotnik, nr 350, 21 grudnia 1926 roku.

Wczorajszy wybór i nowa sytuacja, „Robotnik” nr 149, 1 czerwca 1926 roku.

Wiadomości z ostatniej chwili, „Głos Kobiet. Wydawnictwo Centralnego Wydziału Kobiecego P.P.S." 14 maja 1926 roku.

Żarnowski J., Polska Partia Socjalistyczna, [w:] Życie polityczne w Polsce 1918-1939, red. J. Żarnowski, Wrocław 1985. s. 63-86. 


\section{THE POSITION OF THE POLISH SOCIALIST PARTY AGAINST THE MAY COUP D'ETAT IN 1926}

\section{Summary}

The aim of the article is to present the standpoints of the Polish Socialist Party against the May coup d'Etat in 1926. The paper brings close the actual influence of socialists and dependent on trade unions within the preparation and course on the May coup d'Etat 1926. The author analyses the role and influence of the socialist past of Marshal Jozef Pilsudski in obtaining the support of the leftist forces in the decisive moments of the 1926 coup d'Etat. The article contains a comparative analysis of the political postulates of the Polish Socialist Party as well as the actions taken by the leading groupings aimed at carrying out political and system reforms in the Second Polish Republic. It was shown that the concept of Polish socialists, adopted at the beginning of the 1920s, consisting of achieving program objectives through gradual and non-revolutionary socio-political reforms, paradoxically was abandoned in 1926 in favour of solutions characteristic for revolutionary groups.

Keywords: the doctrine of Polish socialists 1918-1939, Józef Pilsudski, Polish Socialist Party, statism, May coup d'Etat, Polish authoritarianism in the Second Polish Republic, sanation, trade unions in the Second Polish Republic in 1918-1939, parliamentarism in the Second Polish Republic.

Wawrzyniec Kowalski

wawrzyniec.kowalski@wat.edu.pl 